\title{
Presentation of acute coronary syndromes during covid-19 pandemia: attitude of patients and health care professionals
}

\section{Covid-19 pandemisi sırasında akut koroner sendromların başvuru özellikleri: hastaların ve sağlık çalışanlarının tutumu}

Ahmet Karagöz, Zeki Yülksel Günaydın, Aslı Vural, Devrim Kurt, Fatih Özdemir, Fatih Özçubukcu

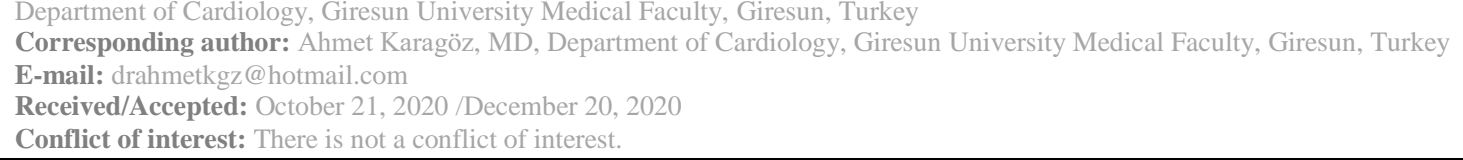

\section{SUMMARY}

Objective: COVID-19 pandemia resulted in substantial alterations in health care demand and delivery. The aim of this study is to investigate presentations and treatment strategies of acute coronary syndromes during COVID-19 pandemia.

Method: The patients presented with acute coronary syndrome between March 10 2020-June 12020 and in the same trimeframe in 2019 were analysed retrospectively. The patients in 2020 constituted the Pandemia group and the patients in 2019 were accepted to be controls. Presentation types, demographical and clinical characteristics as well as treatment strategies were compared between two groups.

Results: There was a $15.2 \%$ reduction in the number of acute coronary syndromes during the COVID-19 pandemia lockdown when compared to previous year. The number of patients presenting with STEMI was higher in Pandemia group when compared to controls $(\mathrm{p}=0.033)$. Less patients underwent coronary angiography and percutaneous coronary intervention in Pandemia group ( $\mathrm{p}=0.012$ and $\mathrm{p}=0.033$, respectively). Antiagregant choice of physicians between clopidogrel and ticagrelol was similar $(\mathrm{p}=0.227)$. Aspartate aminotransferase and lactate dehidrogenase levels were significantly higher in Pandemia group compared to controls $(\mathrm{p}=0.030$ and $\mathrm{p}=0.003$, respectively). Hospitalization duration was similar between two groups while serum levels of troponin on the discharge day was significantly higher in Pandemia group ( $\mathrm{p}=0.512$ and $\mathrm{p}=0.001$, respectively).

Conclusions: COVID-19 pandemia resulted in a decline in the number of acute coronary syndromes and a trend towards conservative approach in patients with NSTEMI. It is contraversial whether mortality benefit driven from COVID-19 prevention is greater than the consequences these presentation and treatment alterations in heart attack patients.

Keywords: COVID-19, Pandemia, Acute coronary syndrome

(D) Ahmet Karagöz
(D) Zeki Yüksel Günaydın
(D) Aslı Vural
(D) Devrim Kurt
(D) Fatih Özdemir
(D) Fatih Özçubukcu

ORCID IDs of the authors: A.K. 0000-0002-3548-1276 Z.Y.G. 0000-0001-9779-7578 A.V. 0000-0002-6601-8778

D.K. 0000-0003-4230-3248

F.Ö. 0000-0003-4318-9491

F.Ö. 0000-0001-8096-929X 
Amaç: COVID-19 pandemisi, sağlık hizmeti talep ve sunumunda önemli değişikliklere neden oldu. Bu çalışmanın amacı, COVID-19 pandemisine bağlı kısıtlamalar sırasında akut koroner sendromların başvuru şekillerini ve tedavi stratejilerini araştırmaktır.

Yöntem: 10 Mart 2020 ve 1 Haziran 2020 tarihleri arasında ve 2019' un aynı zaman diliminde akut koroner sendrom ile başvuran hastalar retrospektif olarak incelendi. 2020'deki hastalar Pandemi grubunu oluştururken, 2019' daki hastalar ise Kontrol grubu olarak kabul edildi. Başvuru şekilleri, demografik ve klinik özellikler ve tedavi stratejileri iki grup arasında karşılaş̧ırıld1.

Bulgular: COVID-19 pandemisi sırasında akut koroner sendrom sayısında bir önceki yıla göre \%15,2' lik bir azalma gözlendi. Pandemi grubunda STEMI ile başvuran hasta sayısı kontrol grubuna göre daha yüksekti $(p=0.033)$. Pandemi grubunda daha az sayıda hastaya koroner anjiyografi ve perkütan koroner girişim uygulandı (sırasıyla $p=0.012$ ve $p=$ 0.033). Klopidogrel ve tikagrelol arasındaki antiagregan seçimi benzerdi $(\mathrm{p}=0.227)$. Aspartat aminotransferaz ve laktat dehidrogenaz düzeyleri, Pandemi grubunda Kontrol grubuna göre anlamlı derecede yüksekti (sırasıly $p=0.030$ ve $p=$ 0.003). Hastanede yatı̧s süresi iki grup arasında benzer iken taburculuk gününde serum troponin düzeyleri Pandemi grubunda anlamlı olarak daha yüksek saptandı (sirasıyla $p=0.512$ ve $p=0.001$ ).

Sonuç: COVID-19 pandemisi, akut koroner sendromların sayısında azalma ve NSTEMI hastalarında konservatif yaklaşım yönünde bir eğilim ile sonuçlanmıştır. COVID-19 önlenmesinden kaynaklanan mortalite faydasının, kalp krizi hastalarındaki bu başvuru ve tedavi değişikliklerinin ortaya çıkardığı sonuçlardan daha fazla olup olmadığı tartışmalıdır. Anahtar sözcükler: COVID-19, pandemi, akut koroner sendrom

\section{INTRODUCTION}

The Globe has faced with an extraordinary infectious disease recently. The first cases were reported in Wuhan-China in December 2019. The accumulation of serious pneumonia cases in hospitals and inability to isolate well-known pathogens raised suspicion of a possible unknown pathogen which is identified and named as SARS$\mathrm{CoV}-2$ afterwards. This new virus (SARS-CoV-2) belongs to the same severe acute respiratory syndrome-coronavirus (SARS-CoV) and Middle East respiratory syndrome-coronavirus (MERS$\mathrm{CoV}$ ) family. Coronavirus disease 2019 (COVID19) has rapidly spread worldwide and adopted to be a pandemia by World Heart Organization (WHO) in March 11 2020. Many countries have announced lockdown since then and most of the hospitals were reorganized as pandemia centers.

Beyond COVID-19 disease, acute coronary syndromes (ACS) continue to be the leading cause of mortality. While pandemia hospitals halted elective interventional procedures during lockdown, catheter laboratories have continued to admit patients presenting with ACS. On the other hand, since hospitals were considered to be the most hazardous places in terms of being infected, most patients hesitated to apply to hospitals even in the presence of severe symptoms. Chest pain is one of the most worrying symptoms in patients and the leading cause of emergency department admissions. Could the fear of being infected prevent hospital admission even in patients with chest pain? This study aimed to investigate the presentation of acute coronary syndromes and attidute of patients as well as the health care professsionals during COVID-19 pandemia lockdown.

\section{MATERIAL AND METHODS}

A total of 146 patients were included in the study. The study had a retrospective design. Sixty seven patients who presented with acute coronary syndrome between March 102020 and June 12020 constituted the Pandemia group. March 102020 was the day when first COVID-19 case was reported in Turkey, and June 12020 was the day when end of lockdown and beginning of newnormal life was announced by the government. The patients were analysed retrospectively from the hospital recordings. Seventy nine patients presented with acute coronary syndrome between March 102019 and June 1 2019, briefly in the same timeframe of the previous year were recruited as the Control group. Demographical characteristics, presentation types, laboratory findings, hospitalization durations and tratment approaches including choice of conservative or invazive strategy were compared between two groups.

\section{Definitions}

Diagnosis of acute coronary syndrom was established under the guidance of Expert Consensus Document on Fourth universal definition of myocardial infarction published in $2018^{1}$. Patients with persistent chest discomfort or other symptoms suggestive of ischaemia and STsegment elevation in at least two contiguous leads or new bundle branch blocks with ischaemic repolarization patterns along with evidence of myocardial injury (defined as an elevation of cardiac troponin values with at least one value 
above the 99th percentile upper reference limit) were accepted as ST elevation myocardial infarction (STEMI). ST elevation on electrocardiogram was defined as new STelevation at the J-point in two contiguous leads with the cut-point: $\geq 1 \mathrm{~mm}$ in all leads other than leads V2-V3 where the following cut-points apply: $\geq 2 \mathrm{~mm}$ in men $\geq 40$ years; $\geq 2.5 \mathrm{~mm}$ in men $<40$ years, or $\geq 1.5 \mathrm{~mm}$ in women regardless of age. Patients with acute chest pain but no persistent STsegment elevation (ECG changes may include transient ST-segment elevation, persistent or transient ST-segment depression, T-wave inversion, flat $\mathrm{T}$ waves or pseudo-normalization of $\mathrm{T}$ waves or the ECG may be normal) with evidence of myocardial injury (defined as an elevation of cardiac troponin values with at least one value above the 99th percentile upper reference limit) were accepted as non ST elevation myocardial infarction (NSTEMI). Unstable angina pectoris (USAP) was defined as myocardial ischaemia at rest or minimal exertion in the absence of cardiomyocyte necrosis demonstrated by normal cardiac troponin values.

\section{Statistical analysis}

Statistical analysis was performed using SPSS version 11.0 (SPSS Inc, Chicago, IL, USA) pocket program. The data were expressed as the mean \pm standard deviation (SD) and were tested for normal distribution using the Kolmogorov-Smirnov test. Comparisons between patients were made by using Student's independent t-test for normally distributed data and Mann-Whitney U test for nonnormal distributed data. The chi-square test was used to compare the categorical variables. A p value of $<0.05$ was considered statistically significant.

\section{RESULTS}

The number of patients presented with acute coronary syndrome was 67 during lockdown and they were defined as Pandemia group. Control group consisted of 79 patients who presented with acute coronary syndrome during the same timeframe in 2019 . There was a $15.2 \%$ reduction in the number of acute coronary syndromes during the COVID-19 pandemia lockdown when compared to previous year. The number of patients presenting with STEMI was higher in Pandemia group when compared to controls $(\mathrm{p}=0.033)$ while the number of patients with NSTEMI was similar $(\mathrm{p}=0.033$ and $\mathrm{p}=0.054$, respectively). There was no statistically significant difference between two groups in terms of age, gender and presence of hypretension, diabetes mellitus and chroic renal failure. The number of patients who underwent coronary angiography was lower in Pandemia group $(\mathrm{p}=0.012)$. Moreover percutaneous coronary intervention rates were also lower in Pandemia group ( $\mathrm{p}=0.033)$. Coronary artery bypass grafting rates were similar between two groups $(\mathrm{p}=0.165)$. Antiagregant choice of physicians between clopidogrel and ticagrelol was similar $(\mathrm{p}=0.227)$. There was no statistically significant difference between Pandemia and Control groups in terms of serum sodium, potassium, LDL cholesterol, total cholesterol, alanine aminotransferase, hemoglobin A1C, glucose and creatinine levels. Serum HDL cholesterol levels were lower in Pandemia group $(\mathrm{p}=0.049)$ while aspartate aminotransferase and lactate dehidrogenase levels were significantly higher. $(\mathrm{p}=0.030$ and $\mathrm{p}=0.003$, respectively). Hospitalization duration was similar between two groups while serum levels of troponin on the discharge day was significantly higher in Pandemia group ( $\mathrm{p}=0.512$, and $\mathrm{p}=0.001$, respectively). 
Table 1: Comparision of demographical and clinical characteristics between Pandemia and Control groups

\begin{tabular}{llll}
\hline & Pandemia group (n:67) & Control group (n:79) & P \\
\hline Age & $65.5( \pm 13.6)$ & $66.6( \pm 11.5)$ & 0.601 \\
STEMI (n, \%) & $47(70.1 \%)$ & $67(84.8 \%)$ & $\mathbf{0 . 0 3 3}$ \\
Gender (Female, \%) & $22(32.8 \%)$ & $19(24.1 \%)$ & 0.344 \\
NSTEMI (n, \%) & $20(29.9 \%)$ & $13(16.5 \%)$ & 0.054 \\
Daibetes Mellitus & $18(26.9 \%)$ & $26(32.9 \%)$ & 0.398 \\
Hypertension & $60(89.6 \%)$ & $63(79.7 \%)$ & 0.105 \\
CRF & $2(3 \%)$ & $5(6.3 \%)$ & 0.337 \\
Na & $138.9( \pm 3.2)$ & $139.7( \pm 3.2)$ & 0.151 \\
K & $4.4( \pm 0.5)$ & $4.5( \pm 0.7)$ & 0.167 \\
HDL Cholesterol & $38(23-73)$ & $42(22-103)$ & 0.049 \\
LDL Cholesterol & $108.5(37-203)$ & $102.5(14-195)$ & 0.083 \\
Total Cholesterol & $172.0(109-310)$ & $174.5(94-318)$ & 0.380 \\
Triglyceride & $137.5(46-767)$ & $141.5(46-575)$ & 0.695 \\
AST & $27.0(11-431)$ & $21.5(8-327)$ & $\mathbf{0 . 0 3 0}$ \\
ALT & $24.5(7-154)$ & $20.0(7-368)$ & 0.796 \\
LDH & $247.0(110-993)$ & $226.0(112-691)$ & $\mathbf{0 . 0 4 8}$ \\
HbA1C & $5.9(4.8-13.8)$ & $5.8(5.0-11-7)$ & 0.911 \\
Glucose & $109.0(75-426)$ & $112(57-414)$ & 0.523 \\
BUN & $42(15-133)$ & $35(20-236)$ & 0.933 \\
Creatinine & $0.9(0.3-3.0)$ & $0.9(0.2-3.7)$ & 0.710 \\
WBC & $8.3(4.1-19.4)$ & $8.1(4.5-29.6)$ & 0.978 \\
Hb & $13.8(9.9-17.4)$ & $13.4(8.7-17.1)$ & 0.246 \\
Platellet & $239(142-422)$ & $233(109-470)$ & 0.450 \\
\hline
\end{tabular}

STEMI: St elevation myocardial infarction, NSTEMI: Non St elevation myocardial infarction, CRF: Chronic renal failure, LDH: Lactate dehidrogenase, Na: Sodium, K: Potassium, HDL: High density lipoprotein, LDL: Low density lipoprotein, AST: Aspartate aminotransferase, ALT: Alanine aminotransferase, LDH: Lactate dehidrogenase, Hb: Haemoglobin, BUN: Blood urea nitrogen, WBC: White blood cell

Table 2: Comparision of treatment strategies between Pandemia and Control groups

\begin{tabular}{llll}
\hline & Pandemia group (n:67) & Control group (n:79) & P \\
\hline CAG & $45(67.2 \%)$ & $67(84.8 \%)$ & $\mathbf{0 . 0 1 2}$ \\
PCI & $37(55.2 \%)$ & $57(72.2 \%)$ & $\mathbf{0 . 0 3 3}$ \\
CABG & $5(7.5 \%)$ & $2(2.5 \%)$ & 0.165 \\
Ticagrelol & $20(29.8 \%)$ & $31(39.2 \%)$ & 0.227 \\
Hospitalization duration & $3(1-15)$ & $3(1-24)$ & 0.894 \\
Troponin on discharge day & $0.34(0.01-8.00)$ & $0.03(0.02-6.00)$ & $\mathbf{0 . 0 0 1}$ \\
\hline
\end{tabular}

CAG: Coronary angiography, PCI: Percutaneous coronary intervention, CABG: Coronary artery bypass grafting

\section{DISCUSSION}

The number of acute coronary syndromes diagnosed during COVID-19 pandemia lockdown were lower when compared with the same timeframe in 2019. On the other hand, the number of STEMI cases were higher during lockdown. There was a tendency for NSTEMI patients to be treated conservatively since the number of CAG and PCI were significantly lower in Pandemia group. Duration of hospitalization was similar between two groups but serum levels of troponin on discharge day was significantly higher in Pandemia group.
With the world health organization declaring COVID-19 disease as a pandemia, a climate of fear prevailed all over the world. Most of the countries announced intermittant or continuous lockdown. Elective outpatient clinic visits were suspended and the public was warned to apply to the hospitals only in emergency conditions. All these seemed to effect the hospital admission behaviours of the patients even in the presence of chest pain, the most worrying symptom for the patients. Recent reports have presented that the lockdown imposed due to the spread of COVID-19 infection has led to a change in the number and type of cardiology admissions in Italy ${ }^{2-4}$. Similar findings were 
reported from United States ${ }^{5-7}$. Tan W. et al reported single center trends in acute coronary sendromes ${ }^{8}$. Reduction in the number of cases were presented from United Kingdom by Wilson SJ et al ${ }^{9,10}$. Decline in the number of cases was also noticeable in Austria, France, Germany, Switzerland, Hong Kong and Egypt 11-18. These reports have demonstrated single or multi-center experiences about acute coronary syndrome admissions during COVID-19 pandemia. As it is seen the pandemia effected hospital admission for acute coronary syndromes all over the world. Our study results were also consistent with the previous reports. Although the total number of acute coronary syndromes including STEMI and NSTEMI was lower during pandemia, the ratio of STEMI was higher. This can be interpreted as increased chest pain treshold for patients to admit emergency departments. Significant amount of NSTEMI cases probably remained undiagnosed due to the fear of being infected.

Beside number of acute coronary syndromes, we also aimed to investigate frequency of interventional procedures. The number of patients who underwent coronary angiography was significantly lower in Pandemia group. In our center, all patients with STEMI underwent urgent coronary angiography and none received fibrinolytic therapy in accordance with the position statement of EAPCI on invasive management of acute coronary syndromes during the COVID-19 pandemia [19]. On the other hand, it seems that here was a tendency for conservative approach in patients with NSTEMI when decline in the number of interventional procedures is considered.

The major symptoms of COVID-19 disease were identified to be fewer and dyspnea. Since dyspnea is the most frequently seen side affect of ticagrelol, antiaggregant choice of the physicians was also compared between two groups. Did the concern that ticagrelol may mask COVID-19 disease have any effect on choice of antiaggregant therapy? This probably made no sense among physicians since rates of clopidogrel and ticagrelol use were similar. Another significant point is higher levels of lactate dehidrogenase and aspartate aminotransferase in the Pandemia group which demonstrates more myocardial damage. This may arise from longer delay in hospital admission. Moreover higher levels of troponin on discharge day in the Pandemia group was also an indicator of more damaged myocardium even in treated patients.

The outcomes of our study demonstrated a downwards trend in the hospital admissions of acute coronary syndromes. These findings were in line with the previous reports that have shown a magnificient decline in the number of acute coronary syndromes from various countries. To the best of our knowledge this is the first scientific document to report the decrease in the number of acute coronary syndromes in the COVID-19 pandemia in Turkey. Although reduction in the number of overall hospital admissions was an expected finding, neglection of chest pain, the most worrying symptom for patients, was surprising. The fear of being infected probably raised the treshold for the patients to apply emergency departments.

Lack of some other demographical data such as family history and smoking status as well as clinical data such as onset to door time and door to balloon time can be considered as a limitation. However our study has a retrospective design and all the data were collected following announcement of the end of the lockdown after the patients were discharged. Unfortunately the above mentioned demographical and clinical data were not available in our recordings. Moreover this study reveals the outcomes from a single center. A multicenter design would probably better reflect the overall trend in our country. On the other hand the majority of the previous studies were reported from single centers.

Consequently, similar reports from all over the world proves that decline in the number of acute coronary syndromes was not occasional. COVID19 fear resulted in "at home" heart attacks. It is controversial whether staying at home in order to prevent COVID-19 disease had advantage over the poor outcomes associated with neglected acute coronary syndromes in terms of mortality.

\section{REFERENCES}

1. Thygesen K, Alpert JS, Jaffe AS, Chaitman BR, Bax JJ, Morrow DA, White HD; Executive Group on behalf of the Joint European Society of Cardiology (ESC)/American College of Cardiology (ACC)/American Heart Association (AHA)/World Heart Federation (WHF) Task Force for the Universal Definition of Myocardial Infarction. Fourth Universal Definition of Myocardial Infarction (2018). Glob Heart 2018; 13: 305-38. doi: 10.1016/j.gheart.2018.08.004.

2. Vecchio S, Fileti L, Reggi A, Moschini C, Lorenzetti S, Rubboli A. Impatto della pandemia COVID-19 sui ricoveri per sindrome coronarica acuta: revisione della letteratura ed esperienza monocentrica [Impact of the COVID-19 pandemic on admissions for acute coronary syndrome: review of the literature and single-center experience]. G Ital Cardiol (Rome) 2020; 21: 5028. doi: 10.1714/3386.33635. 
3. De Rosa S, Spaccarotella C, Basso C, Calabrò MP, Curcio A, Filardi PP, Mancone M, Mercuro G, Muscoli S, Nodari S, Pedrinelli R, Sinagra G, Indolfi C; Società Italiana di Cardiologia and the CCU Academy investigators group. Reduction of hospitalizations for myocardial infarction in Italy in the COVID-19 era. Eur Heart J 2020 ; 41: 20838. doi: 10.1093/eurheartj/ehaa409.

4. Di Liberto IA, Pilato G, Geraci S, Milazzo D, Vaccaro G, Buccheri S, Caramanno G. Impact on hospital admission of ST-elevation myocardial infarction patients during coronavirus disease 2019 pandemic in an Italian Hospital. J Cardiovasc Med (Hagerstown) 2020; 21: 722-4. doi: 10.2459/JCM.0000000000001053.

5. Zitelny E, Newman N, Zhao D. STEMI during the COVID-19 Pandemic - An Evaluation of Incidence. Cardiovasc Pathol 2020; 48: 107232. doi: 10.1016/j.carpath.2020.107232.

6. Garcia S, Albaghdadi MS, Meraj PM, Schmidt C, Garberich R, Jaffer FA, Dixon S, Rade JJ, Tannenbaum M, Chambers J, Huang PP, Henry TD. Reduction in ST-Segment Elevation Cardiac Catheterization Laboratory Activations in the United States During COVID-19 Pandemic. J Am Coll Cardiol 2020; 75: 2871-2. doi: 10.1016/j.jacc.2020.04.011.

7. Braiteh N, Rehman WU, Alom M, Skovira V, Breiteh N, Rehman I, Yarkoni A, Kahsou H, Rehman A. Decrease in acute coronary syndrome presentations during the COVID-19 pandemic in upstate New York. Am Heart J 2020; 226: 147-51. doi: 10.1016/j.ahj.2020.05.009.

8. Tan W, Parikh RV, Chester R, Harrell J, Franco V, Aksoy O, Dave R, Rafique A, Press M. Single Center Trends in Acute Coronary Syndrome Volume and Outcomes During the COVID-19 Pandemic. Cardiol Res 2020; 11: 256-9. doi: 10.14740/cr1096.

9. Wilson SJ, Connolly MJ, Elghamry Z, Cosgrove C, Firoozi S, Lim P, Sharma R, Spratt JC. Effect of the COVID-19 Pandemic on ST-SegmentElevation Myocardial Infarction Presentations and In-Hospital Outcomes. Circ Cardiovasc Interv 2020; 13: e009438. doi: 10.1161/CIRCINTERVENTIONS.120.009438.

10. Abdelaziz HK, Abdelrahman A, Nabi A, Debski M, Mentias A, Choudhury T, Patel B, Saad M. Impact of COVID-19 pandemic on patients with ST-segment elevation myocardial infarction: Insights from a British cardiac center. Am Heart J 2020; 226: 45-8. doi: 10.1016/j.ahj.2020.04.022.

11. Metzler B, Siostrzonek P, Binder RK, Bauer A, Reinstadler SJ. Decline of acute coronary syndrome admissions in Austria since the outbreak of COVID-19: the pandemic response causes cardiac collateral damage. Eur Heart J 2020; 41: 1852-3. doi: 10.1093/eurheartj/ehaa314.

12. Huet F, Prieur C, Schurtz G, Gerbaud E, Manzo-Silberman S, Vanzetto G, Elbaz M, Tea V, Mercier G, Lattuca B, Duflos C, Roubille F. One train may hide another: Acute cardiovascular diseases could be neglected because of the COVID-19 pandemic. Arch Cardiovasc Dis 2020; 113: 303-7. doi: 10.1016/j.acvd.2020.04.002.

13. Hauguel-Moreau M, Pillière R, Prati G, Beaune $\mathrm{S}$, Loeb T, Lannou S, Mallet S, Mustafic H, Bégué C, Dubourg O, Mansencal N. Impact of Coronavirus Disease 2019 outbreak on acute coronary syndrome admissions: four weeks to reverse the trend. J Thromb Thrombolysis 2020: 12. doi: 10.1007/s11239-020-02201-9. Epub ahead of print.

14. Lantelme $\mathrm{P}$, Couray Targe S, Metral $\mathrm{P}$, Bochaton T, Ranc S, Le Bourhis Zaimi M, Le Coanet A, Courand PY, Harbaoui B. Worrying decrease in hospital admissions for myocardial infarction during the COVID-19 pandemic. Arch Cardiovasc Dis 2020; 113: 443-7. doi: 10.1016/j.acvd.2020.06.001.

15. Tam CF, Cheung KS, Lam S, Wong A, Yung A, Sze M, Lam YM, Chan C, Tsang TC, Tsui M, Tse HF, Siu CW. Impact of Coronavirus Disease 2019 (COVID-19) Outbreak on ST-SegmentElevation Myocardial Infarction Care in Hong Kong, China. Circ Cardiovasc Qual Outcomes 2020; 13: e006631. doi: 10.1161/CIRCOUTCOMES.120.006631.

16. Kessler T, Graf T, Hilgendorf I, Rizas K, Martens E, von Zur Mühlen C, Kraemer P, MeyerSaraei R, Neumann FJ, Bode C, Laugwitz KL, Massberg S, Schunkert H, Weil J, Kastrati A, Sager HB. Hospital admissions with acute coronary syndromes during the COVID-19 pandemic in German cardiac care units. Cardiovasc Res 2020; 116: 1800-1. doi: 10.1093/cvr/cvaa192.

17. Holy EW, Jakob P, Manka R, Stähli BE, Siegrist PT, Ruschitzka F, Templin C. Impact of a nationwide COVID-19 lockdown on acute coronary syndrome referrals. Cardiol J 2020. doi: 10.5603/CJ.a2020.0091. Epub ahead of print.

18. Said K, El-Baghdady Y, Abdel-Ghany M. Acute coronary syndromes in developing countries during the COVID-19 pandemic. Eur Heart J 2020: ehaa507. doi: 10.1093/eurheartj/ehaa507. Epub ahead of print. 